\title{
PENGEMBANGAN LATIHAN TAEKWONDO DENGAN MEDIA AUDIO-VISUAL UNTUK EKSTRAKURIKULER TAEKWONDO DI SMA KABUPATEN TULUNGAGUNG
}

\author{
Wahid Rohmat Setianto \\ Heru Widijoto \\ Sulistyorini \\ Fakultas Ilmu Keolahragaan Universitas Negeri Malang \\ E-mail: dananjayatian@gmail.com
}

\begin{abstract}
Abstrack: The research was conducted with the aimed to develop practice-based audiovisual taekwondo for taekwondo in high school extracurricular Tulungagung. This research includes research and development. The products resulting from this research is packaged in a VCD. To get a result the researchers used three experts that media experts, expert coaching and taekwondo expert. As for the small group trial with 6 students obtained $86.22 \%$ and the results of testing large groups with 38 students obtained result of $89.32 \%$. So it can be concluded that this product is valid and can be used.
\end{abstract}

Keywords: taekwondo exercise, audio-visual, extracurricular

\begin{abstract}
Abstrak: Penelitian ini dilaksanakan dengan tujuan untuk mengembangkan latihan taekwondo berbasis audio-visual untuk ekstrakurikuler taekwondo di SMA Kabupaten Tulungagung. Penelitian ini termasuk jenis penelitian dan pengembangan. Produk yang dihasilkan dari penelitian ini dikemas dalam bentuk VCD. Untuk mendapat hasil peneliti menggunakan 3 ahli yaitu ahli media, ahli kepelatihan dan ahli taekwondo. Sedangkan untuk uji coba kelompok kecil dengan 6 siswa diperoleh hasil $86,22 \%$ serta uji coba kelompok besar dengan 38 siswa diperoleh hasil $89,32 \%$. Jadi dapat disimpulkan bahwa produk ini valid dan dapat digunakan.
\end{abstract}

Kata kunci: latihan taekwondo, audio-visual, ekstrakurikuler

Taekwondo adalah olahraga beladiri modern yang berakar pada beladiri tradisional Korea yang berarti seni atau cara mendisiplinkan diri atau seni beladiri yang menggunakan teknik kaki dan tangan kosong. Dasar-dasar Taekwondo terbentuk dari kombinasi berbagai teknik gerakan menyerang dan bertahan yang menggunakan bagian tubuh kita untuk menghadapi lawan.

Cabang olahraga Taekwondo umumnya menekankan pada tendangan dari pada pukulan. Teknik tendangan menjadi sangat penting karena kekuatannya jauh lebih besar daripada tangan, walaupun teknik tendangan secara umum lebih sukar dilakukan daripada tangan. Namun dengan latihan yang baik dan benar akan meningkatkan kualitas tendangan secara signifikan. Di masa kini Taekwondo tidak hanya sebagai alat perlindungan diri. Dengan diadakannya pertan- dingan Taekwondo, saat ini Taekwondo sudah menjadi olahraga yang syarat akan prestasi dan sudah pasti potensi-potensi yang ada dapat lebih berkembang melalui olahraga ini.

Sebagai olahraga prestasi taekwondo tidak hanya berdiri di klub, tetapi Di tingkat sekolah, ekstrakurikuler diharapkan menjadi wadah yang tepat untuk mengembangkan potensi siswa dan sarana menyalurkan minat dan bakat siswa. Peraturan Menteri Pendidikan dan Kebudayaan RI Nomor 81A tahun 2013 tentang Implementasi Kurikulum yang menjelaskan bahwa "ekstra kurikuler adalah kegiatan pendidikan yang dilakukan oleh peserta didik di luar jam belajar kurikulum dan dilakukan dibawah bimbingan sekolah dengan tujuan untuk mengembangkan kepribadian, bakat, minat, dan kemampuan peserta didik yang lebih luas 
Wahid Rohmat Setianto, Pengembangan Latihan Taekwondo dengan Media Audio Visual untuk Ekstra Kurikuler

atau di luar minat yang dikembangkan oleh kurikulum".

Menurut Prihatin (2011:164) ekstra kurikuler adalah "kegiatan yang dilakukan di luar jam pelajaran biasa dan pada waktu libur sekolah yang dilakukan baik di sekolah maupun luar sekolah".

Kegiatan ekstrakurikuler adalah kegiatan yang dilaksanakan oleh guru dan siswa di luar jam sekolah yang telah ditentukan dalam kurikulum yang berlaku (Zayd, 2011). Dari ketiga pendapat tersebut dapat disimpulkan ekstrakurikuler adalah kegiatan siswa diluar kurikulum yang ada dalam proses belajar di sekolah. Ekstrakurikuler adalah wadah bagi siswa untuk mengem-bangkan potensi yang dimiliki. Setiap siswa tentunya memiliki potensi, minat dan bakat yang berbeda, mulai dari renang, voli atau bahkan olahraga beladiri seperti Taekwondo.

Beladiri lahir dari kebutuhan hidup manusia untuk mempertahankan hidupnya. "bela diri sepenuhnya berarti melindungi diri sendiri, keluarga atau teman-teman dari para penyerang (Goodman, 1994:vi). "TaeKwonDo terdiri dari 3 kata tae berarti kaki atau menghancurkan dengan tendangan, Kwon berarti tangan menghantam dan mempertahankan diri dengan teknik tangan, serta Do berarti seni cara mendisiplinkan diri. Maka jika diartikan secara sederhana, Taekwondo berarti seni atau cara mendisiplinkan diri atau seni beladiri yang menggunakan kaki dan tangan kosong"(Marlina, 2008: 2).

Menurut Suryadi (2003:

"taekwondo-in harus bertindak disiplin sesuai dengan standar tinggi yang telah ditetapkan dan diberlakukan oleh organisasi Tae Kwon Do di manapun di seluruh dunia. Hal itu diterapkan untuk mengembangkan pemahaman nilai-nilai pada generasi muda, guna meng-hasilkan tingkat kehormatan dan kesopanan yang tinggi, serta merupakan dasar kuat bagi moralitas yang sangat diperlukan dewasa ini. Taekwondo mengembangkan tingkah laku yang rendah hati, saling menghargai, keber-samaan, dan tata cara yang baik. Formalitas dalam taekwondo menghasilkan sifat yang tidak egois, kebaikan, dan toleransi".

Dari pernyataan diatas dapat disimpulkan bahwa taekwondo tidak hanya melatih dengan kegiatan fisik saja tetapi juga mengajarkan budi pekerti dan moral kepada
anggotanya.Tetapi untuk dapat menerapkan kebaikan budi pekerti peserta latihan juga harus memahami sejarah, filosofi dan juga tatakrama dalam taekwondo. Jadi tidak hanya mempelajari dari gerakan dan teknik saja tetapi juga memahami semua ajaran tentang taekwondo.

Di tingkat sekolah, ekstrakurikuler diharapkan menjadi wadah yang tepat untuk mengembangkan potensi siswa dan sarana menyalurkan minat dan bakat siswa. Seperti dijelaskan Peraturan Menteri Pendidikan dan Kebudayaan RI Nomor 81A tahun 2013 tentang Implementasi Kurikulum yang menjelaskan bahwa"ekstra kurikuler adalah kegiatan pendidikan yang dilakukan oleh peserta didik di luar jam belajar kurikulum dan dilakukan dibawah bimbingan sekolah dengan tujuan untuk mengembangkan kepribadian, bakat, minat, dan kemampuan peserta didik yang lebih luas atau di luar minat yang dikembangkan oleh kurikulum". Merujuk dari hal tersebut jelas sekali terlihat bahwa melalui ekstrakurikuler Taekwondo siswa dapat mengembangkan potensi yang dimiliki.

Mengikuti perkembangan teknologi yang kita miliki saat ini, penyampaian materi latihan Taekwondo dapat lebih efektif. Media video memiliki kelebihan mudah dipelajari, hal ini tentu saja sangat membantu bagi perkembangan potensi peserta ekstrakurikuler Taekwondo, karena dalam mempelajari suatu teknik gerakan dengan cara melihat video bisa dimana saja tidak harus pada saat latihan. Dan juga video dapat diputar berulang-ulang dan diperlambat untuk melihat dengan jelas teknik dari suatu gerakan.

Media adalah "segala bentuk dan saluran yang dapat digunakan dalam proses penyajian informasi. Media adalah alat atau cara yang digunakan sebagai perantara untuk menyampaikan informasi (pesan) agar dapat diterima oleh penerima informasi sepenuhnya" (Dwiyogo, 2010:229). Menurut Sadiman (2003:6) media adalah "segala sesuatu yang dapat digunakan untuk menyalurkan pesan dari pengirim ke penerima sehingga dapat merangsang pikiran, perasaan, perhatian dan minat serta perhatian siswa sedemikian rupa sehingga proses belajar terjadi". Menurut Arsyad (2011:3) pengertian media adalah "proses belajar mengajar cenderung diartikan se- 
bagai alat-alat grafis, photografis, atau elektronis untuk menangkap, memproses, dan menyusun kembali informasi visual dan verbal".

Beberapa pendapat dari para ahli, dapat disimpulkan bahwa media adalah komponen alat yang dapat digunakan untuk mengirimkan informasi pembelajaran kepada siswa sebagai penerima informasi yang berfungsi untuk merangsang minat belajar siswa.Pada penelitian dan pengembangan yang dilakukan, pelatihan taekwondo dikemas dalam bentuk VCD sebagai media yang ditayangkan pada saat pelaksanaan pembelajaran melalui proyektor LCD.

"VCD adalah sebuah disc plastik yang digunakan untuk merekam suara, gambar, dan bahkan simbol atau lambang, dan juga suara dan gambar tersebut bisa ditayangkan atau ditampilkan kembali melalui VCD player dan monitor televisi" (Heinich, 1982). "Compact video disc adalah sistem penyimpanan dan rekaman video dimana signal audiovisual direkam pada disket plastik, bukan pada pita magnetic" (Arsyad, 2011:36). "Media VCD tergolong dalam jenis media elektronik yang bergerak dan dinamis dapat dilihat dan didengar dalam menyampaikan pesannya melalui alat elektronika" (Zulkarnain, dkk, 2011).

Dari teori para ahli dapat disimpulkan bahwa vcd adalah disket plastik yang digunakan sebagai media untuk menyimpan audio-visual yang dapat dibawa kemanamana, dapat dilihat dan didengar dalam menyampaikan pesannya melalui alat elektronik.

Menurut Darmawan (2012:16) media audio-visual adalah: Teknologi audiovisual merupakan cara memproduksi dan menyampaikan bahan dengan menggunakan peralatan mekanis dan elektronis untuk menyajikan pesan audio dan visual. Pembe-lajaran audiovisual dapat dikenal dengan mudah karena menggunakan perangkat keras di dalam proses pengajaran. Peralatan audiovisual memungkinkan untuk memproyeksikan gambar hidup, pemutaran kembali suara, dan penayangan visual yang berukuran besar.

Media audio-visual adalah "media pandang dengar yang menampilkan gambar dan suara, seperti lazimnya televisi, film bersuara, dan video. Sebelum era kom- puter, media ini dipandang sebagai yang paling "sophisticated" karena mampu memadukan unsur suara dan gambar, yang sebelumnya masih terpisah" (Dwiyogo, 2010:334). Sedangkan menurut Arsyad (2011:30) teknologi audio-visual "cara menghasilkan atau menyampaikan materi dengan menggunakan mesin-mesin mekanis dan elek-tronik untuk menyajikan pesanpesan audio-visual'.

Berdasar penelitian terdahulu yang dilakukan oleh Permana (2013:25) "media audio visual saat ini sudah semakin populer dan digemari masyarakat kita". Tapi yang membedakan penelitian ini dengan penelitian tersebut adalah penelitian ini mengarah pada pengembangan video latihan taekwondo untuk ekstrakurikuler SMA, sedangkan penelitian tersebut lebih mengarah pada pengembangan latihan karet ban untuk meningkatkan power tendangan dollyo chagi dengan kaki kiri.

Dapat disimpulkan bahwa media audiovisual adalah sebuah media yang menyajikan informasi berupa audio dan visual secara utuh kepada penerima informasi. Pada penelitian dan pengem-bangan ini, produk berupa pelatihan taekwondo dikemas dalam bentuk VCD yang dapat menyajikan informasi berupa audio dan visual sehingga penyampaian isi produk pelatihan taekwondo dapat lebih mudah tersampaikan.

Sebagaimana yang telah tertulis diatas bahwa media audio-visual adalah media yang menyajikan informasi berupa audio dan visual untuk dikirimkan kepada penerima informasi yang berguna untuk mengefektifkan interaksi antara pelatih dan siswa dalam proses latihan. Pemilihan media harus dikembangkan sesuai dengan tujuan yang ingin dicapai.

Berdasarkan hasil observasi tanggal 31 desember 2014 pada SMAN 1 Pakel, SMAN 1 Kauman, dan SMAN 1 Boyolangu di Tulungagung yang memilih Taekwondo sebagai ekstrakurikuler. Hasil wawancara kepada 3 pelatih Taekwondo di 3 SMA Tersebut disimpulkan bahwa peserta latihan Taekwondo adalah anak-anak yang berpotensi, tetapi ditemukan permasalahan peserta kegiatan Taekwondo kesulitan memahami konsep-konsep dasar yang ada dalam Taekwondo, mulai dari teknik dasar, filosofi sabuk dan gerakan. Peserta mudah lupa 
Wahid Rohmat Setianto, Pengembangan Latihan Taekwondo dengan Media Audio Visual untuk Ekstra Kurikuler

dengan materi latihan, dikarenakan latihan hanya diadakan dua kali dalam seminggu. belum adanya media untuk membantu mereka mempelajari materi latihan Taekwondo di rumah mereka masing-masing diluar latihan ekstrakurikuler.

Dari hasil observasi dapat disimpulkan bahwa para pelatih setuju adanya suatu media yang dapat membantu mereka untuk mengajarkan pemahaman tentang Taekwondo yang mudah dipelajari anak-anak dimana saja mereka berada, tidak harus di tempat latihan. Berdasarkan permasalahan tersebut peneliti telah melakukan penelitian yang berjudul "Pengembangan Latihan Taekwondo dengan Media Audio Visual untuk Ekstra Kurikuler Taekwondo di SMA Kabupaten Tulungagung". Tujuan penelitian ini adalah untuk mengembangkan latihan Taekwondo dengan media audio visual sebagai sarana memberikan pemahaman tentang konsep dan teknik dasar Taekwondo kepada peserta ekstrakurikuler Tekwondo di SMA Kabupaten Tulungagung.

\section{METODE}

Model penelitian dan pengembangan yang digunakan dalam melakukan penelitian dan pengembangan latihan taekwondo ini adalah model prosedural. Model prosedural adalah model yang bersifat deskriptif, yaitu menggariskan langkah-langkah yang harus diikuti untuk menghasilkan produk (PPKI, 2010:47).

Penelitian ini menggunakan model prosedural. dalam penerapan pengembangan ini peneliti menggunakan pengembangan milik Borg dan Gall (1983:775) yang terdiri dari 1) Penelitian dan pengumpulan data (research and information collection), analisis kebu-tuhan, studi literatur, penelitian dalam skala kecil, dan pertimbanganpertimbangan dari segi nilai, 2) Perencanaan (planning). Menyusun rencana penelitian, meliputi ke-mampuan yang diperlukan dalam pelak-sanaan penelitian tersebut, desain atau lang-kah-langkah penelitian kemungkinan peng-ujian dalam lingkungan terbatas, 3) Pengem-bangan draf produk (develop prelimetery-form of product). Pengembangan bahan pembelajaran, proses pembelajaran dan instrumen evaluasi, 4) Uji coba lapangan awal (preliminary field testing). Uji coba di lapangan pada 1 sampai 3 sekolah dengan 6-12 subjek uji coba (guru). Selama uji coba diadakan pengamatan, wawancara dan penyebaran angket, 5) Merevisi hasil uji coba (main product revision). Memperbaiki atau menyempurnakan hasil uji coba. 6) Uji coba lapangan (main field testing). Melakukan uji coba yang lebih luas pada 5sampai dengan 15 sekolah dengan 30 sampai dengan 100 orang subjek uji coba. Data kuantitatif penampilan guru sebelum dan sesudah menggunakan model yang diuji cobakan kemudian dikumpulkan.

Hasil-hasil pengumpulan data, dievaluasi dan bila memungkinkan bisa dibandingkan dengan kelompok pembanding, 7) Penyem-purnaan produk hasil uji lapangan (operational product revision). Menyem-purnakan produk hasil uji lapangan, 8) Uji pelaksanaan lapangan (operational field testing). Dilaksanakan pada 10 sampai dengan 30 sekolah melibatkan 40 sampai dengan 200 subjek. Pengujian dilakukan melalui angket, wawancara, observasi dan analisis hasilnya 9) Penyempurnaan produk akhir (final product revision). Penyempurnaan didasar-kan masukan dari uji pelaksanaan lapangan, 10) Diseminasi dan implementasi (dissemination and implementtation).

Dari 10 langkah pengembangan yang dikemukakan oleh Borg dan Gall peneliti tidak dapat melakukan semua langkah secara keseluruhan karena adanya keterbatasan-keterbatasan yang dimiliki oleh peneliti. Maka dalam melakukan penelitian ini peneliti menyederhanakan langkahlangkah tersebut. Seperti yang telah diungkapkan oleh Ardhana (2002:9) langkahlangkah pengembangan yang dikemukakan tersebut, tidak harus diikuti secara menyeluruh, tetapi memilih dan mencan-tumkan langkah-langkah yang paling tepat bagi dirinya berdasarkan kondisi khusus yang dihadapinya dalam proses pengembangan.

Seperti yang telah peneliti ungkapkan sebelumnya dalam melakukan penelitian dan pengembangan latihan taekwondo dengan media audio-visual ini peneliti tidak menggunakan semua langkah prosedur yang telah dikemukakan oleh Borg and Gall karena adanya keterbatasan-keterbatasan yang dimiliki oleh peneliti. Pengembangan 
produk ini dilakukan dalam beberapa tahap, yaitu:

(1) Melakukan penelitian awal, pengum-pulan data dan informasi termasuk kajian pustaka dan observasi lapangan di ekstra-kurikuler Taekwondo di SMA N 1 Pakel, SMA N 1 Kauman, SMA N 1 Boyolangu Kabupaten Tulungagung. (2) Mengem-bangkan produk awal berupa rancangan produk. (3) Produk awal kemudian dievaluasi dari satu ahli kepelatihan, ahli media dan ahli Taekwondo. (4) Uji coba kelompok kecil dengan subyek 6 orang. (5) Revisi produk awal yang sesuai dengan kegiatan uji coba kelompok kecil. (6) Uji coba lapangan kelompok besar dengan subyek subyek 38 orang. (7) Revisi produk yang sesuai dengan kegiatan uji coba kelompok besar. Hasil akhir produk pengembangan dari hasil revisi produk akhir.

Pada penelitian dan pengembangan ini, ada beberapa subyek penelitian yang terlibat adalah: a) subyek penelitian awal (analisis kebutuhan) sebanyak 3 orang pelatih Taekwondo. Masing-masing dari SMAN 1 Pakel, SMAN 1 Boyolangu, SMAN 1 Kauman, b) subyek evaluasi ahli terdiri dari ahli media pembelajaran, ahli kepelatihan, dan ahli Taekwondo, c) subyek uji coba kelompok kecil adalah perwakilan responden setiap SMA sebanyak 2 siswa totalnya sebanyak 6 siswa.

Subyek uji coba lapangan kelompok besar adalah perwakilan SMAN 1 Pakel 8 siswa, SMAN 1 Boyolangu 15 siswa, SMAN 1 Kauman 15 siswa. Totalnya sebanyak 38 siswa.

Evaluasi ahli dilakukan oleh 3 orang ahli yaitu 1 orang ahli media, 1 orang ahli kepelatihan, dan 1 orang ahli taekwondo. Sedangkan subjek uji coba kelompok kecil yaitu siswa yang mengikuti kegiatan ekstrakurikuler taekwondo di 3 SMA Kabupaten Tulungagung (SMAN 1 Pakel, SMAN 1 Kauman, SMAN 1 Boyolangu) sebanyak 6 siswa dan uji coba kelompok besar sebanyak 38 siswa.

Jenis data yang didapat merupakan data kualitatif dan kuantatif. Data kualitatif diperoleh dari tinjauan 1 orang ahli pelatihan, 1 ahli media, dan 1 orang ahli Taekwondo. Data kuantitatif diperoleh dari analisis kebutuhan untuk mengetahui persentase kebutuhan produk yang dikembangkan serta dari data uji coba kelompok kecil dan uji coba kelompok besar.

Instrumen pengumpulan data yang digunakan dalam pengembangan ini adalah kuisioner. Kuisioner ini digunakan untuk mengumpulkan data kuantatif analisis kebutuhan dan penilaian tanggapan siswa peserta ekstrakurikuler Taekwondo di SMAN 1 Pakel, SMAN 1 Kauman, SMAN 1 Boyolangu di Kabupaten Tulungagung. Sedangkan pendekatan kualitatif untuk mendapatkan saran dan masukan dari para ahli tentang rancangan produk yang akan dibuat.

Teknik analisis data yang digunakan dalam penelitian dan pengembangan ini adalah sebagai berikut. Data kualitatif berupa masukan para ahli yang digunakan untuk revisi terhadap rancangan produk. Data tersebut diperoleh saat analisis kebutuhan dan evaluasi ahli. Data kuantitatif berupa presentase dari pemberian angket terhadap ekstrakurikuler taekwondo. Data tersebut diperoleh dari hasil pengumpulan data uji coba kelompok kecil dan uji coba kelompok besar.

\section{HASIL}

Pada bagian hasil penelitian dan pengembangan disajikan data yang diperoleh dari kegiatan penelitian dan pengembangan latihan taekwondo dengan media audiovisual untuk ekstrakurikuler taekwondo di SMA Kabupaten Tulungagung. Data hasil uji coba terdiri dari data tinjaun para ahli, uji kelompok kecil dan uji kelompok besar. Data awal yang diperoeh dari analisis kebutuhan, pengumpulan data berupa wawancara kepada pelatih ekstrakurikuler taekwondo di SMAN 1 Pakel, SMAN 1 Kauman, SMAN 1 Boyolangu. Pengumpulan data hasil tinjauan para ahli menggunakan teknik kuesioner meliputi data hasil tinjauan 3 orang ahli, yaitu ahli media, ahli kepelatihan, dan ahli taekwondo. Sedangkan Data hasil uji coba kelompok kecil yang tediri dari 6 siswa peserta ekstra-kurikuler taekwondo dan uji kelompok besar terdiri dari 38 siswa adalah data yang diperoleh dari jawaban instrumen yang disajikan dalam bentuk angket/ kuesioner.

Hasil wawancara kepada 3 pelatih Taekwondo di 3 SMA Tersebut disimpulkan 
Wahid Rohmat Setianto, Pengembangan Latihan Taekwondo dengan Media Audio Visual untuk Ekstra Kurikuler Taekwondo di SMA Kabupaten Tulungagung

bahwa peserta latihan Taekwondo adalah anak-anak yang berpotensi, tetapi ditemukan permasalahan peserta kegiatan Taekwondo kesulitan memahami konsep-konsep dasar yang ada dalam Taekwondo, mulai dari teknik dasar, filosofi sabuk dan gerakan. Peserta mudah lupa dengan materi latihan, dikarenakan latihan hanya diadakan dua kali dalam seminggu. belum adanya media untuk membantu mereka mempelajari materi latihan Taekwondo di rumah mereka masing-masing diluar latihan ekstrakurikuler. Dari hasil observasi dapat disimpulkan bahwa para pelatih setuju adanya suatu media yang dapat membantu mereka untuk mengajarkan pemahaman tentang taekwondo.

Dari hasil evaluasi ahli media didapatkan saran sebagai berikut, gambar disusun perbagian, slow motion dan secara cepat. font dan warna perlu diubah dan dibuat menarik. Caption disusun lebih menarik dengan memberikan warna dan menam-bahkan penanda pada bagian tubuh yang dianggap penting. kemenarikan caption perlu diubah ditingkatkan dengan mengubah font dan jenis tulisan. Perlu ditambahkan penan-da pada bagian penting tubuh yang menjadi sasaran. gambar harus dipilih secara detail tentang sejarah perjalanan Taekwondo. keseimbangan suara narator dengan musik background perlu disesuaikan. Intonasi suara perlu diperbaiki sehingga secara narasi lebih menarik. Judul video diganti judul yang lebih menarik. Nama penyusun disertai foto. Disusun gambar perbagian, slow motion dan secara keseluruhan. Ditambahkan tampilan yang menampilkan keseluruhan gerakan atau rangkaian gera-kan. Sarana dan prasarana Taekwondo diletakan di depan, setelah penjelasan seja-rah Taekwondo. Bab dan sub bab disusun berbeda sehingga mudah untuk dipahami. Perlu ditambahkan halaman cover, profil penulis, sinopsis di cover belakang buku. Perlu ditambahkan gerakan perbagian dan keseluruhan.

Berdasarkan paparan hasil evaluasi ahli media tersebut, dan setelah ahli media mengamati produk latihan Taekwondo dengan media audio visual yang dikemas dalam bentuk VCD dan disertai buku panduan, dapat disimpulkan secara keseluruhan bahwa produk dapat digunakan dengan revisi kecil dalam latihan ekstrakurikuler Taekwondo di SMA.

Dari hasil dari uji evaluasi ahli kepelatihan didapatkan saran sebagai berikut, Dima-sukan dalam video/buku. Sebaiknya penje-lasan dalam video atau bukunya. Sebaiknya ada penjelasan dalam video atau bukunya. Sebaiknya penjelasan dalam video atau bukunya. Sebaiknya ditunjukan dalam video atau bukunya. Sebaiknya ditunjukan dalam video atau bukunya. Beban latihan secara progresif sebaiknya ditampilkan dalam video/buku. Setuju, tetapi narasi video tidak ada. Harus diadakan. Sebaiknya item-item gerakannya diberikan penjelasan atau narasi. Sebaiknya dalam sejarah ada narasinya kata-kata. "pelatihan" sebaiknya dipertimbangkan lagi.

Berdasarkan paparan hasil evaluasi ahli kepelatihan tersebut, dan setelah ahli kepelatihan mengamati produk latihan Taekwondo dengan media audio visual yang dikemas dalam bentuk VCD dan disertai buku panduan, dapat disimpulkan secara keseluruhan bahwa produk dapat digunakan dengan revisi kecil dalam latihan ekstrakurikuler Taekwondo di SMA.

Dari hasil evaluasi ahli taekwondo didapatkan saran sebagai berikut, Setuju, filosofi seragam dan sabuk di letakan setelah sejarah. Diganti satu laki-laki dan satu perempuan sebagai motivasi untuk peserta perempuan. Setuju, letakan setelah sejarah. Setuju, narasi diperjelas. Sederhanakan menjadi dua pukulan dasar, eolgol jurugi dan momtong jurugi. Tambah dengan latihan menendang target. Dilakukan oleh laki-laki dan perempuan bersamaan.

Berdasarkan paparan hasil evaluasi ahli Taekwondo tersebut, dan setelah ahli Taekwondo mengamati produk latihan Taekwondo dengan media audio visual yang dikemas dalam bentuk VCD dan disertai buku panduan, dapat disimpulkan secara keseluruhan bahwa produk dapat digunakan dengan revisi kecil dalam latihan ekstrakurikuler Taekwondo di SMA.

Hasil Analisis Data Uji Coba Tahap I (Kelompok Kecil). Berdasarkan hasil evaluasi uji coba kelompok kecil mendapatkan persentase kemenarikan 90,7\%, kejelasan $81,9 \%$, kesesuaian $87,5 \%$, kemudahan $84,7 \%$, dan jumlah nilai rata-rata yang didapat adalah $86,22 \%$. Sehingga produk yang dikembangkan dinyatakan sangat valid 
dan dapat digunakan dalam latihan ekstrakurikuler taekwondo di SMA.

Hasil Analisis Data Uji Coba Tahap II (Kelompok Besar). Berdasarkan hasil hasil evaluasi uji coba kelompok besar persentase kemenarikan mendapatkan nilai 90,7\%, kejelasan mendapatkan nilai $81,9 \%$, kesesuaian mendapatkan nilai $87,5 \%$, kemudahan mendapatkan nilai $84,7 \%$, dan jumlah nilai rata-rata yang didapat adalah $89,32 \%$. Sehingga produk yang dikembangkan dinyatakan sangat valid dan dapat digunakan dalam latihan ekstrakurikuler taekwondo di SMA.

\section{PEMBAHASAN}

Produk yang dihasilkan dalam pengembangan ini adalah latihan teknik dasar Taekwondo berbasis audio-visual yang disertai dengan buku panduan. Di dalam pengembangan latihan teknik dasar Taekwondo dengan media audio-visual ini berisikan tentang materi sejarah Taekwondo, filosofi seragam dan sabuk, teknik dasar serangan dan tangkisan dalam Taekwondo. Latihan teknik dasar Taekwondo yang berbasis media audio-visual ini dilengkapi dengan video, gambar, caption dan narasi. Sehingga diharapkan memiliki daya tarik bagi pengguna yang ingin mempelajarinya. disamping itu, adanya buku panduan latihan teknik dasar Takwondo yang berisi tentang langkah-langkah operasional dan isi video, dilengkapi dengan gambar gerakan teknik dasar Taekwondo yang sesuai dengan isi dalam VCD. Menurut Darmawan (2012:16) media audio-visual adalah:

Teknologi audiovisual merupakan cara memproduksi dan menyampaikan bahan dengan menggunakan peralatan mekanis dan elektronis untuk menyajikan pesan audio dan visual. Pembelajaran audiovisual dapat dikenal dengan mudah karena menggunakan perangkat keras di dalam proses pengajaran. Peralatan audiovisual memungkinkan untuk memproyeksikan gambar hidup, pemutaran kembali suara, dan penayangan visual yang berukuran besar.

Media audio-visual adalah "media pandang dengar yang menampilkan gambar dan suara, seperti lazimnya televisi, film bersuara, dan video. Sebelum era komputer, media ini dipandang sebagai yang paling "sophisticated" karena mampu memadukan unsur suara dan gambar, yang sebelumnya masih terpisah" (Dwiyogo, 2010:334). Sedangkan menurut Arsyad (2011:30) teknologi audio-visual "cara menghasilkan atau menyampaikan materi dengan menggunakan mesin-mesin mekanis dan elektronik untuk menyajikan pesanpesan audio-visual".

Berdasar penelitian terdahulu yang dilakukan oleh Permana (2013:25) "media audio visual saat ini sudah semakin populer dan digemari masyarakat kita". Tapi yang membedakan penelitian ini dengan penelitian tersebut adalah penelitian ini mengarah pada pengembangan video latihan taekwondo untuk ekstrakurikuler SMA, sedangkan penelitian tersebut lebih mengarah pada pengembangan latihan karet ban untuk meningkatkan power tendangan dollyo chagi dengan kaki kiri.

Dengan demikian dapat disimpulkan bahwa media audio-visual adalah sebuah media yang menyajikan informasi berupa audio dan visual secara utuh kepada penerima informasi. Pada penelitian dan pengembangan ini, produk berupa pelatihan taekwondo dikemas dalam bentuk VCD yang dapat menyajikan informasi berupa audio dan visual sehingga penyampaian isi produk pelatihan taekwondo dapat lebih mudah tersampaikan.

"VCD adalah sebuah disc plastik yang digunakan untuk merekam suara, gambar, dan bahkan simbol atau lambang, dan juga suara dan gambar tersebut bisa ditayangkan atau ditampilkan kembali melalui VCD player dan monitor televisi" (Heinich, 1982). "Compact video disc adalah sistem penyimpanan dan rekaman video dimana signal audio-visual direkam pada disket plastik, bukan pada pita magnetic" (Arsyad, 2011:36). "Media VCD tergolong dalam jenis media elektronik yang bergerak dan dinamis dapat dilihat dan didengar dalam menyampaikan pesannya melalui alat elektronika" (Zulkarnain, dkk, 2011).

Dari teori para ahli dapat disimpulkan bahwa vcd adalah disket plastik yang digunakan sebagai media untuk menyimpan audio-visual yang dapat dibawa kemanamana, dapat dilihat dan didengar dalam 
Wahid Rohmat Setianto, Pengembangan Latihan Taekwondo dengan Media Audio Visual untuk Ekstra Kurikuler

menyampaikan pesannya melalui alat elektronik.

Berdasarkan data yang dikumpulkan dari ahli media, ahli kepelatihan, ahli Taekwondo dan peserta ekstrakurikuler Taekwondo SMA di Kabupaten Tulungagung melalui uji coba tahap I (kelompok kecil) dan uji coba tahap II (kelompok besar), ada beberapa produk perlu direvisi agar produk yang dikembang-kan lebih sempurna dan lebih optimal.

Berikut adalah ringkasan revisi berdasarkan saran dari para ahli, Intonasi pembacaan narasi diperbaiki agar lebih mudah dipahami. Filosofi seragam dan sabuk diletakan setelah sejarah. Judul video diganti lebih tepat dan menarik. Gerakan diperagakan laki-laki dan perempuan. Ditambahkan latihan dengan menendang target. Masukan beberapa prinsip latihan. Tempat pengambilan gambar dipindah ke dojang dan ditambah gerakan perbagian dan keseluruhan. Nama penyusun disertai foto, serta foto dan narasi disesuaikan bab. Ditambahkan halaman cover, profil penulis, sinopsis di cover belakang buku.

\section{KESIMPULAN}

Dapat disimpulkan dari penelitian yang dilakukan pada produk pengembangan latihan taekwondo dengan media audio-visual untuk ektrakurikuler taekwondo di SMA Kabupaten Tulungagung diperoleh kesimpulan bahwa model latihan yang diberikan menarik, menyenangkan, aman, mudah, dan bermanfaat untuk latihan taekwondo di ekstrakurikuler taekwondo SMA Kabupaten Tulungagung. Sehingga dapat disimpulkan bahwa, produk latihan taekwondo berbasis audio-visual memenuhi syarat kelayakan untuk digunakan pada latihan taekwondo di ekstrakurikuler taek-wondo SMA Kabupaten Tulungagung.

\section{SARAN}

Hasil akhir dari kegiatan penelitian dan pengembangan ini adalah berupa produk latihan Taekwondo dengan media Audiovisual untuk ekstrakurikuler taekwondo di SMA. Produk latihan teknik dasar Taekwondo untuk ekstrakurikuler Taekwondo SMA yang dikemas dalam bentuk VCD juga disertakan buku panduan tersebut. Produk ini menggunakan metode pengembangan dan mengacu pada rancangan penelitian pada model pengembangan Borg And Gall, kemudian produk ini mempunyai kelebihan sebagai panduan peserta ekstrakurikuler taekwondo untuk berlatih teknik dasar Taekwondo di rumah.

Pengembangan latihan taekwondo dengan media audio visual yang dikemas dalam bentuk VCD dan juga disertai buku panduan untuk pelaksanaan latihan teknik dasar taekwondo yang dikembangkan. Dengan menggunakan media audio visual ini peserta latihan dimudahkan untuk mempelajari teknik dasar taekwondo dimanapun. Siswa juga dibantu dengan adanya buku panduan latihan teknik dasar taekwondo yang berisikan mengenai langkah-langkah melakukan latihan sesuai dengan video yang ditayangkan.

Berdasarkan tinjauan para ahli (1 orang ahli media, 1 orang ahli kepelatihan, dan 1 orang ahli taekwondo), uji coba kelompok kecil, uji coba kelompok besar, maka diperoleh hasil akhir (produk) yang telah direvisi, meliputi: (1) Intonasi pembacaan narasi diperbaiki agar lebih mudah dipahami. (2) Filosofi seragam dan sabuk diletakan setelah sejarah. (3) Judul video diganti lebih tepat dan menarik. (4) Gerakan diperagakan laki-laki dan perempuan. (5) Ditambahkan latihan dengan menendang target. (6) Masukan beberapa prinsip latihan. (7) Tempat pengambilan gambar dipindah ke dojang dan ditambah gerakan perbagian dan keseluruhan. (8) Nama penyusun disertai foto, serta foto dan narasi disesuaikan bab. (9) Ditambahkan halaman cover, profil penulis, sinopsis di cover belakang buku.

Selain hasil revisi dari tinjauan para ahli, uji coba kelompok kecil dan besar, tentunya produk ini masih memiliki banyak kekurangan. Namun dengan kendala yang dihadapi semoga penelitian ini dapat bermanfaat dan juga dapat dipertimbang-kan dalam pelaksanaan penelitian selanjutnya.

Pengembangan model latihan taekwondo dengan media audio visual ini diharapkan kepada para peserta latihan akan lebih tertarik untuk mempelajari gerakan teknik dasar taekwondo. Diharapkan dapat mem-bantu mereka menguasai teknik serangan maupun ber-tahan dengan benar, karena dengan adanya video ini 
dapat menjadi panduan ketika berlatih sendiri di rumah.

Pengembangan model latihan taekwondo dengan media audiovisual ini diharapkan dapat membantu pelatih dalam menyam-paikan materi latihan kepada peserta latihan ekstrakurikuler taekwondo di SMA.

Bagi lembaga pendidikan SMA di Tulunggagung diharapkan dengan adanya pengembangan latihan taekwondo dengan media audiovisual ini diharapkan dapat membantu sekolah dalam mengoptimalkan potensi yang dimiliki siswa peserta latihan ekstrakurikuler taekwondo di SMA.

Pengembangan latihan taekwondo dengan media audio visual ini diharapkan oleh peneliti agar menambah pengalaman nyata dan pengaplikasian pengetahuan yang didapat selama perkuliahan. Selain itu penelitian ini digunakan sebagai penyusunan skripsi untuk mendapatkan gelar sarjana.

Sebagai upaya penyebarluasan produk yang telah dikembangkan ke sasaran yang lebih luas, peneliti memberikan saran untuk disosialisasikan kepada pelatih taekwondo di SMA lainnya diluar Kabupaten Tulungagung, sehingga produk ini memperoleh pengakuan sebagai pengembangan latihan taekwondo dengan media audio visual yang layak untuk disebarluaskan.

Adapun saran dari peneliti mengenai pengembangan latihan taekwondo kepada siapa saja yang akan melanjutkan pengembangan latihan taekwondo ini, sebaiknya hasil pengembangan latihan lebih dikhususkan pada teknik-teknik tertentu karena pada pengembangan ini hanya digunakan untuk membahas latihan teknik dasar Taekwondo untuk ekstrakurikuler di SMA Kabupaten Tulungagung.

\section{DAFTAR PUSTAKA}

Akbar \& Sriwijaya. 2010. Pengembangan Kurikulum dan Pembelajaran. Malang: Cipta Media

Ardhana, Wayan. 2002. Konsep Penelitian Pengembangan Dalam Bidang Pendidikan dan Pembelajaran. Malang: Universitas Negeri Malang.
Arsyad, Azhar. 2011. Media Pembelajaran. Jakarta: Rajawali Pers.

Borg, W.R. \& Gall, M.D. 1983. Educational Research An Introduction. New York: Longman.

Darmawan, Deni. 2012. Inovasi Pendidikan (Pendekatan Praktik Teknologi Multimedia dan Pembelajaran Online). Bandung: PT Remaja Rosdakarya

Dwiyogo, Wasis D. 2010. Dimensi Teknologi Pembelajaran Pendidikan Jasmani Dan Olahraga. Malang: Wineka Media.

Goodman, Fay 1994. Beladiri Untuk Semua Umur. Jakarta: Ghalia Indonesia.

Heinich, 1982. Instuctional Media and The New Technologies of Instuction. New York : John Wiley and Sons. (Online).(http://www.sarjanaku.com/ 2012/12/pengertian-media-vcddalam-pembelajaran.html), diakses 25 januari 2015.

Marlina, Lina 2008. Tae Kwon Do. Jakarta: Ganeca Exact.

Peraturan Menteri Pendidikan dan Kebudayaan Republik Indonesia Nomor 81A Tahun 2013 tentang Implementasi Kurikulum Pedoman Kegiatan Ekstrakurikuler. (Online). (http: //abkin.org/download/lampiran-iiipedoman-kegiatanekstrakurikuler.Pdf), diakses 20 Februari 2015

Prihatin, Eka 2011. Manajemen Peserta Didik. Bandung: Alfabeta.

Sadiman, Arif, S, dkk. 2003. Media Pendidikan (Pengertian, Pengembangan, dan Pemanfaatannya). Jakarta: Grafindo Persada.

Suryadi, Yoyok. 2002. Tae Kwon Do Poomse Tae Geuk. Jakarta: Gramedi Pustaka Utama. 
Wahid Rohmat Setianto, Pengembangan Latihan Taekwondo dengan Media Audio Visual untuk Ekstra Kurikuler

Zayd, Nasr Hamid. 2011. Definisi Kegiatan Ekstrakurikuler,(Online)

(http://kafeilmu.com/definisi-

kegiatan-ekstrakurikuler/), diakses 23 maret 2015

Zulkarnain, Elfian., Leersia, Yursi, R., \& Nikmatul, Farida. 2011. Perbedaan Efektifitas Antara Video Compact Disc (VCD) Dalam Meningkatkan Pengetahuan dan Sikap lbu Hamil Terhadap Inisiasi Menyusui Dini. Jurnal disajikan dalam seminar Nasional Jampersal, Fakultas Kesehatan Masyarakat, Jember, 26 November 2011 (online), (http://fkm. unej.ac.id/file/semnas2011/05.pdf) diakses 25 Januari 2015 